\title{
PENGARUH PELATIHAN PENCEGAHAN DEMAM BERDARAH DENGUE (DBD) TERHADAP TINGKAT PENGETAHUAN DAN SIKAP SISWA DI SDN WIROGUNAN I KARTASURA KABUPATEN SUKOHARJO
}

\author{
Sugiyono$^{1}$, Sri Darnoto \\ ${ }^{1}$ Dinas Kesehatan Kabupaten Intan Jaya. Email: ${ }^{1}$ sugiyonoskm@gmail.com \\ ${ }^{2}$ Program Studi Kesehatan Masyarakat Fakultas Ilmu Kesehatan \\ Universitas Muhammadiyah Surakarta. Email: ${ }^{2}$ darnoto@ums.ac.id
}

\begin{abstract}
ABSTRAK
Penyakit Demam Berdarah Dengue (DBD) merupakan penyakit akibat infeksi virus dengue yang masih menjadi masalah kesehatan masyarakat Indonesia. Penyakit ini menyerang semua kelompok umur, namun sebagian besar berusia di bawah 15 tahun. Siswa Sekolah Dasar (SD) merupakan kelompok rentan yang kepeduliannya sangat diperlukan guna menjaga kesehatan bagi masyarakat sekolah. Sehingga, membutuhkan pengetahuan dan sikap yang baik terhadap upaya Pemberantasan Sarang Nyamuk (PSN). Peningkatan pengetahuan dan sikap siswa dapat dilakukan dengan memberikan pelatihan kesehatan. Penelitian ini bertujuan untuk mengetahui pengaruh pelatihan pencegahan DBD terhadap tingkat pengetahuan dan sikap siswa di SDN Wirogunan I. Metode penelitian menggunakan penelitian eksperimen yang dilengkapi dengan pendekatan metode kuantitatif. Rancangan penelitian yang digunakan yaitu rancangan pra eksperimen dengan bentuk one group pretest and posttest design. Jumlah sampel pada penelitian ini sebanyak 57 siswa. Pengambilan sampel dalam penelitian ini menggunakan teknik non probability sampling dengan metode sampling jenuh. Uji statistik menggunakan uji t-test dengan wilcoxon signed ranks test. Hasil penelitian menunjukkan ada pengaruh pelatihan pencegahan DBD terhadap tingkat pengetahuan $(p=0,000)$ dan sikap siswa $(p=0,000)$ di SDN Wirogunan I.
\end{abstract}

Kata Kunci : Penyakit DBD, Siswa SD, Pengetahuan dan Sikap

\begin{abstract}
Dengue Hemorrhagic Fever (DHF) disease is a disease caused by dengue virus infection remains a public health problem in Indonesia. This disease attacks all age groups, though for the most age is under 15 years old. Elementary School Students are concern for vulnerable groups are needed to maintain the health of the public schools. Thus, it is required a good knowledge and attitude towards the Eradication efforts Mosquitoes Breeding Place. Improving the knowledge and attitude of students can be done by providing training in health. The study aimed to determine the effect of dengue prevention training to the level of knowledge and attitudes of students in SDN Wirogunan I.
\end{abstract}


The research used experimental methods of research that comes with the approach of quantitative methods. The study design used was preexperimental design to form one group pretest and posttest design. The number of samples in this study was consist of 57 students. Sampling in this study was using non probability sampling technique with saturated sampling method. Statistical tests was using test t-test with the Wilcoxon signed ranks test. The results showed that there was no effect of training on dengue prevention knowledge level ( $\mathrm{p}=$ $0.000)$ and attitudes of the students $(\mathrm{p}=0.000)$ in SDN Wirogunan I.

Keywords: DHF Desease, Elementary Students, Knowledge and Attitudes

\section{PENDAHULUAN}

Penyakit Demam Berdarah Dengue (DBD) merupakan salah satu masalah kesehatan masyarakat Indonesia yang jumlah penderitanya cenderung meningkat dan penyebarannya semakin luas. Perjalanan penyakitnya cepat dan dapat menyebabkan kematian dalam waktu singkat serta sering menimbulkan Kejadian Luar Biasa (KLB) (Widoyono, 2008). Penyakit ini menyerang semua kelompok umur, namun sebagian besarnya adalah anak-anak umur 15 tahun ke bawah (Kemkes RI, 2011). Data dari seluruh dunia menunjukkan Asia menempati urutan pertama dalam jumlah penderita DBD setiap tahunnya. Sementara itu, terhitung sejak tahun 1968 hingga tahun 2009, World Health Organization (WHO) mencatat negara Indonesia sebagai negara dengan kasus DBD tertinggi di Asia Tenggara (Brahim dkk, 2010).

Tingginya kasus DBD menandakan masih banyaknya daerah yang endemis di Indonesia. Bahkan sekitar 70\% kabupaten/kota masih termasuk kategori endemis pada tahun 2010 (Rita, 2011). Berdasarkan data dari Direktorat Jenderal Pengendalian Penyakit dan Penyehatan Lingkungan Kementrian Kesehatan Republik Indonesia (Dirjen P2PL Kemkes RI) (2011), diketahui bahwa Provinsi Jawa Tengah menempati urutan kedua tertinggi setelah Provinsi Jawa Timur yakni sejumlah 2.345 kasus DBD dari jumlah penduduk 32.380.687 jiwa (IR=7,24/100.000 penduduk) pada tahun 2011. Hal ini menunjukkan bahwa banyak daerah kabupaten/kota yang merupakan wilayah endemis DBD di Provinsi Jawa Tengah. Dari 35 kabupaten/kota yang ada di Provinsi Jawa Tengah, Kabupaten Sukoharjo merupakan kabupaten yang cenderung mengalami peningkatan jumlah daerah endemis DBD, yakni dari 56 desa/kelurahan endemis pada tahun 2010 menjadi 68 desa/kelurahan endemis pada tahun 2011 (DKK Sukoharjo, 2012).

Kabupaten Sukoharjo memiliki 12 kecamatan dan 11 di antaranya tercatat sebagai wilayah endemis DBD. Pada tahun 2011 terdapat 106 kasus DBD dengan distribusi terbesar di wilayah kerja Puskesmas Grogol yaitu 21 kasus diikuti wilayah kerja Puskesmas Kartasura sebesar 20 kasus (DKK Sukoharjo, 2012). Kecamatan Kartasura memiliki 12 desa/ kelurahan dan 10 di antaranya juga merupakan daerah endemis DBD, salah satunya yaitu Desa Wirogunan (Puskesmas Kartasura, 2012).

Peningkatan kasus DBD itu banyak terjadi di sekolah-sekolah. Sampai saat ini upaya pencegahan penyakit DBD yang dapat dilakukan oleh sekolah-sekolah yaitu melalui kegiatan Usaha Kesehatan Sekolah (UKS), namun tidak semua sekolah telah mengaktifkan kegiatan UKS. Sedangkan, berdasarkan Keputusan 
Menteri Kesehatan (Kepmenkes) No. 1457 Tahun 2003 tentang Standar Pelayanan Minimal (SPM) bidang kesehatan di kabupaten/kota, setiap sekolah memiliki kewajiban menyelenggarakan kesehatan di lingkungan sekolah melalui UKS, yaitu segala usaha yang dilakukan untuk meningkatkan kesehatan anak usia sekolah pada setiap jalur, jenis dan jenjang pendidikan mulai dari TK sampai SLTA. Hal ini dikarenakan kepedulian siswa sangat diperlukan guna menjaga kesehatan bagi masyarakat sekolah, terutama anak-anak usia dini yang rentan terhadap penyakit. Sehingga, kegiatan pendidikan maupun pelatihan kesehatan untuk meningkatkan pengetahun, sikap dan keterampilan untuk senantiasa berperilaku hidup sehat termasuk kegiatan PSN merupakan program yang harus dilaksanakan di lingkungan sekolah. Penelitian Sigarlaki (2007), menyebutkan bahwa semakin tinggi pengetahuan seseorang maka pencegahan terhadap penyakit akan lebih baik pula.

Menurut Kamil (2010), pengetahuan dapat ditingkatkan melalui pelatihan. Konsep dasar pelatihannya yaitu dengan memberikan materi pengetahuan tentang penyakit DBD, nyamuk penular DBD dan memberikan informasi serta motivasi agar nantinya tercipta perilaku yang baik sehingga mampu melaksanakan PSN DBD (Depkes RI, 2007). Penelitian Indrayani (2010), menyimpulkan bahwa pelatihan pencegahan DBD pada siswa Madrasah Ibtidaiyah (MI) mampu meningkatkan pengetahuan dan sikap siswa MI secara signifikan.

Desa Wirogunan merupakan daerah endemis demam berdarah yang cenderung mengalami peningkatan jumlah kasus DBD sejak tahun 2009, yaitu sebanyak 3 kasus pada tahun 2009, 8 kasus pada tahun 2010 dan 9 kasus pada tahun 2011 dengan 89 persen kasus di antaranya berusia di bawah 15 tahun. Pada tahun
2010, pernah terjadi kasus DBD yang menimpa salah satu siswa di SDN Wirogunan I (PKD Wirogunan, 2011).

Berdasarkan hasil survei pendahuluan, terdapat satu sekolah tingkat dasar yang terletak di wilayah sporadis (Dukuh Tisanan) Desa Wirogunan, yaitu SD Negeri (SDN) Wirogunan I. SDN Wirogunan I merupakan sekolah yang kegiatan UKSnya belum aktif, khususnya mengenai program PSN di sekolah tersebut. Pada tahun 2010, pernah terjadi kasus DBD yang menimpa salah satu siswa di sekolah tersebut dan hingga kini siswa-siswi di sekolah tersebut belum pernah mendapatkan pelatihan tentang pencegahan DBD. Sehingga, diperlukan adanya kegiatan yang dapat meningkatkan pengetahuan demi perubahan sikap yang positif pada siswa di SDN Wirogunan I. Oleh karena itu, peneliti ingin meneliti pengaruh pelatihan pencegahan DBD terhadap tingkat pengetahuan dan sikap siswa di SDN Wirogunan I.

Tujuan dari penelitian ini adalah untuk mengetahui pengaruh pelatihan pencegahan DBD terhadap tingkat pengetahuan dan sikap siswa di SDN Wirogunan I.

\section{METODE PENELITIAN}

Penelitian ini merupakan penelitian praeksperimen dengan bentuk one group pretest and posttest design. Populasi dalam penelitian ini adalah seluruh siswa kelas empat dan kelas lima di SDN Wirogunan I. Sebanyak 57 sampel diambil menggunakan teknik nonprobability sampling dengan metode sampling jenuh. Proses pengumpulan data dalam penelitian ini diperoleh dengan melaksanakan pretest dan posttest dengan menggunakan kuesioner yang sudah dilakukan uji validitas dan reliabilitas. Untuk menganalisis data dengan menggunakan Wilcoxon signed ranks test. 
HASIL

Sekolah Dasar Negeri (SDN) Wirogunan I merupakan sekolah tingkat dasar yang terletak di Dukuh Tisanan Desa Wirogunan Kecamatan Kartasura Kabupaten Sukoharjo. Jumlah siswa SDN Wirogunan I yang berada di bangku kelas empat sebanyak 33 siswa dan yang berada di bangku kelas lima sebanyak 24 siswa. Pada saat pelatihan, jumlah siswa yang dapat mengikuti dan bersedia menjadi responden penelitian sejumlah 53 siswa $(93 \%)$ dari 57 siswa.

Berdasarkan data hasil penelitian diketahui nilai median variabel pengetahuan sebesar 7,00; maka pengetahuan responden dinyatakan baik jika memiliki skor lebih dari sama dengan tujuh ( $\geq 7$ ) dan kurang baik jika memiliki skor kurang dari tujuh $(<7)$.

Tabel 1. Tingkat Pengetahuan Responden Sebelum dan Sesudah Pelatihan

\begin{tabular}{ccccc}
\hline Kategori & \multicolumn{2}{c}{ Pretest } & \multicolumn{2}{c}{ Posttest } \\
\cline { 2 - 5 } Pengetahuan & Frekuensi & Persentase (\%) & Frekuensi & Persentase (\%) \\
\hline Baik & 13 & 24,5 & 44 & 83 \\
Kurang baik & 40 & 75,5 & 9 & 17 \\
\hline Jumlah & 53 & 100 & 53 & 100 \\
\hline
\end{tabular}

Berdasarkan Tabel 1, diketahui bahwa tingkat pengetahuan responden sebelum pelatihan (pretest) yang berkategori kurang baik sebanyak 40 responden $(75,5 \%)$ lebih banyak daripada yang berkategori baik, yaitu sebanyak 13 responden $(24,5 \%)$. Selanjutnya, tingkat pengetahuan responden sesudah pelatihan (posttest) yang berkategori baik sebanyak 44 responden (83\%) lebih banyak daripada yang berkategori kurang baik, yaitu sebanyak 9 responden (17\%).

Berdasarkan data hasil penelitian diketahui nilai median variabel sikap sebesar 9,00; maka sikap responden dinyatakan baik jika memiliki skor lebih dari sama dengan sembilan $(\geq 9)$ dan kurang baik jika memiliki skor kurang dari sembilan $(<9)$.

Tabel 2. Tingkat Sikap Responden Sebelum dan Sesudah Pelatihan

\begin{tabular}{ccccc}
\hline Kategori & \multicolumn{2}{c}{ Pretest } & \multicolumn{2}{c}{ Posttest } \\
\cline { 2 - 5 } Sikap & Frekuensi & Persentase (\%) & Frekuensi & Persentase (\%) \\
\hline Baik & 18 & 34 & 37 & 69,8 \\
Kurang baik & 35 & 66 & 16 & 30,2 \\
\hline Jumlah & 53 & 100 & 53 & 100 \\
\hline
\end{tabular}

Berdasarkan Tabel 2, diketahui bahwa tingkat sikap responden sebelum pelatihan yang berkategori kurang baik sebanyak 35 responden $(66 \%)$ lebih banyak daripada yang berkategori baik, yaitu sebanyak 18 responden (34\%). Selanjutnya, tingkat sikap responden sesudah pelatihan yang berkategori baik sebanyak 37 responden $(69,8 \%)$ lebih banyak daripada yang berkategori kurang baik, yaitu sebanyak 16 responden $(30,2 \%)$.
Berdasarkan hasil uji KolmogrovSmirnov, diketahui bahwa tiga data berdistribusi tidak normal karena memiliki $p$-value $\leq 0,05$ dan satu data (pretest pengetahuan) berdistribusi normal karena memiliki $p$-value $\geq 0,05$ yaitu sebesar 0,07 . Sehingga, dapat disimpulkan bahwa teknik pengujian hipotesis penelitian ini menggunakan uji non parametris, yaitu Wilcoxon Signed Ranks Test. 
Tabel 3. Hasil Uji Wilcoxon Variabel Pengetahuan

\begin{tabular}{ccccc}
\hline \multirow{2}{*}{$\begin{array}{c}\text { Variabel } \\
\text { Pengetahuan }\end{array}$} & \multicolumn{2}{c}{ Rata-rata } & pvalue & Kesimpulan \\
\cline { 2 - 3 } & Pretest & Posttest & & \\
\cline { 2 - 5 } & 5,49 & 7,89 & 0,000 & Signifikan \\
\hline
\end{tabular}

Berdasarkan Tabel 3, diketahui $p$ value variabel pengetahuan sebesar 0,000 ( $p$-value $\leq 0,05)$, sehingga hipotesis penelitian diterima. Hasil uji statistik menunjukkan rata-rata posttest pengetahuan $(7,89)$ lebih tinggi dibandingkan rata-rata pretest pengetahuan $(5,49)$. Berdasarkan hasil tersebut dapat disimpulkan bahwa pemberian pelatihan pencegahan DBD berpengaruh terhadap peningkatan pengetahuan siswa di SDN Wirogunan I.

Tabel 4. Hasil Uji Wilcoxon Variabel

\begin{tabular}{|c|c|c|c|c|}
\hline \multicolumn{5}{|c|}{ Sikap } \\
\hline \multirow{3}{*}{$\begin{array}{l}\text { Variabel } \\
\text { Sikap }\end{array}$} & \multicolumn{2}{|c|}{ Rata-rata } & \multirow{2}{*}{$\begin{array}{c}p- \\
\text { value }\end{array}$} & \multirow{2}{*}{ Kesimpulan } \\
\hline & Pretest & Posttest & & \\
\hline & 7,83 & 9,00 & 0,000 & Signifikan \\
\hline
\end{tabular}

Berdasarkan Tabel 4, diketahui $p$ value variabel sikap sebesar 0,000 ( $p$ value $\leq 0,05)$, sehingga hipotesis penelitian diterima. Hasil uji statistik juga menunjukkan rata-rata posttest sikap $(9,00)$ lebih tinggi dibandingkan rata-rata pretest sikap $(7,83)$. Berdasarkan hasil tersebut dapat disimpulkan bahwa pemberian pelatihan pencegahan DBD berpengaruh terhadap peningkatan sikap siswa di SDN Wirogunan I.

\section{PEMBAHASAN}

Berdasarkan hasil uji Wilcoxon variabel pengetahuan didapatkan $p$-value sebesar 0,000 (p-value $\leq 0,05)$; yang berarti bahwa ada pengaruh pelatihan pencegahan DBD terhadap tingkat pengetahuan siswa di SDN Wirogunan I. Hasil uji statistik variabel pengetahuan juga menunjukkan adanya peningkatan nilai rata-rata tingkat pengetahuan siswa yang cukup signifikan, yaitu dari 5,49 pada saat pretest menjadi 7,89 pada saat posttest dari skor maksimal 9; artinya ada peningkatan kualitas pengetahuan responden sebesar 2,4 sesudah pelatihan pencegahan DBD.

Pengetahuan merupakan hasil penginderaan manusia yang sangat dipengaruhi oleh intensitas perhatian dan persepsi terhadap objek (Notoatmodjo, 2007). Berdasarkan data yang diperoleh, tingkat pengetahuan awal responden mayoritas berkategori kurang baik, yaitu sebanyak 40 siswa $(75,5 \%)$; kemudian berubah menjadi mayoritas berkategori baik setelah diberi pelatihan, yaitu sebanyak 44 siswa (83\%). Hal ini sejalan dengan teori Kamil (2010), yang menyatakan bahwa pengetahuan dapat ditingkatkan melalui pelatihan dengan metode kuliah. Berdasarkan data pretest pengetahuan, ditemukan sebanyak 13 siswa $(24,5 \%)$ yang termasuk kategori baik. Beberapa faktor yang berhubungan dengan tingkat pengetahuan tersebut antara lain adalah informasi tentang penyakit DBD. Adanya kejadian penyakit DBD di wilayah kerja Puskesmas Kartasura setiap tahunnya, menyebabkan program-program penanggulangan DBD di wilayah kerja Puskesmas tersebut terus digalakkan hingga begitu akrab kepada masyarakat dan anak-anak. Programprogram tersebut secara tidak langsung membantu anak-anak untuk memahami tentang penyakit DBD termasuk tata cara pencegahan penyakit DBD. Hal tersebut sesuai dengan pendapat Notoatmodjo (2007), yang menyatakan bahwa salah satu faktor yang mempengaruhi pengetahuan seseorang adalah informasi.

Berdasarkan data posttest pengetahuan, ditemukan 9 siswa (17\%) yang berkategori kurang baik. Hal tersebut dikarenakan posttest dilaksanakan pada saat jam pulang sekolah bagi siswa. Sehingga, beberapa siswa nampak kurang serius dalam menjawab pertanyaan kuesioner penelitian. Meskipun demikian, pengaruh pelatihan pencegahan DBD 
terhadap peningkatan pengetahuan dalam penelitian ini signifikan $(p=0,000)$.

Hasil penelitian ini sejalan dengan penelitian Soeparmanto (2006), yang menyatakan bahwa penyuluhan (pelatihan) kesehatan mampu meningkatakan rata-rata pengetahuan secara bermakna, yaitu dari 16 pada saat awal penelitian menjadi 50 pada saat akhir penelitian pada kelompok studi dari skor maksimal 100. Sejalan juga dengan hasil penelitian Puspitasari (2011), yang menyimpulkan bahwa penyuluhan tentang HIV dan AIDS oleh waria efektif dalam meningkatkan pengetahuan waria di Surakarta dengan kenaikan rata-rata sebesar 2,302.

Berdasarkan hasil uji Wilcoxon variabel sikap didapatkan $p$-value sebesar $0,000$ ( $p$-value $\leq 0,05)$; yang berarti bahwa ada pengaruh pelatihan pencegahan DBD terhadap tingkat sikap siswa di SDN Wirogunan I. Hasil uji statistik variabel sikap juga menunjukkan adanya peningkatan nilai rata-rata tingkat sikap siswa yang cukup signifikan dari 7,83 pada saat pretest menjadi 9,00 pada saat posttest dari skor maksimal 10, artinya ada peningkatan kualitas sikap responden sebesar 1,17 sesudah pelatihan pencegahan DBD.

Berdasarkan data yang diperoleh, tingkat sikap awal responden mayoritas berkategori kurang baik, yaitu sebanyak 35 siswa (66\%); kemudian berubah menjadi mayoritas berkategori baik setelah diberi pelatihan, yaitu sebanyak 37 siswa $(69,8 \%)$. Peningkatan kualitas sikap yang positif ini menunjukkan bahwa pelatih (trainer) telah berhasil dalam berkomunikasi dengan peserta pelatihan. Mengingat sikap merupakan respons tertutup seseorang terhadap stimulus atau objek tertentu yang melibatkan faktor pendapat dan emosi yang bersangkutan (Notoatmodjo, 2007). Maka, peningkatan sikap harus didahului dengan pengetahuan dan pemahaman yang baik terhadap objek tersebut. Oleh karena itu, peningkatan sikap dalam penelitian ini didahului dengan pemberian materi mengenai pengertian, virus penyebab, vektor dan upaya penanggulangan DBD dengan metode kuliah (ceramah). Hal ini sesuai dengan teori Azwar (2011), yang menyatakan sikap dapat ditingkatkan melalui pelatihan dengan cara memperhatikan keefektifan suatu pelatihan.

Berdasarkan Kepmenkes No. 1457 Tahun 2003 tentang SPM bidang kesehatan di kabupaten/kota, setiap sekolah memiliki kewajiban menyelenggarakan kesehatan di lingkungan sekolah melalui UKS. Sehingga, kegiatan pendidikan maupun pelatihan kesehatan untuk meningkatkan pengetahun, sikap dan keterampilan untuk senantiasa berperilaku hidup sehat termasuk kegiatan PSN merupakan program yang harus dilaksanakan di lingkungan sekolah. Berdasarkan data pretest sikap, ditemukan sebanyak 18 siswa $(34 \%)$ yang termasuk berkategori baik. Hal ini menunjukkan bahwa pemahaman yang responden miliki sebelum pelatihan sudah mempengaruhi sikap responden. Sedangkan, pada saat posttest sebanyak 37 siswa $(69,8 \%)$ sudah berkategori baik. Mengingat kesehatan merupakan kebutuhan pokok masyarakat di semua aspek kehidupan termasuk di bidang pendidikan, maka SDN Wirogunan I sudah memiliki modal untuk melaksanakan kegiatan PSN dengan cara bekerjasama dengan Bidang P2PL DKK Sukoharjo untuk membentuk tim jumantik kecil di lingkungan sekolah.

Berdasarkan data posttest sikap, ditemukan sebanyak 16 siswa (17\%) yang masih berkategori kurang baik. Hal tersebut dikarenakan posttest dilaksanakan pada saat jam pulang sekolah bagi siswa. Sehingga, beberapa siswa nampak kurang serius dalam menjawab pertanyaan kuesioner penelitian. Meskipun demikian, 
pengaruh pelatihan pencegahan DBDB terhadap peningkatan sikap dalam penelitian ini signifikan $(p=0,000)$.

Hasil penelitian ini sejalan dengan hasil penelitian Fatmawati (2010), yang menyimpulkan bahwa terdapat perbedaan tingkat sikap siswa tentang penyakit menular seksual antara sebelum dan sesudah diberikan intervensi pendidikan kesehatan antara kelompok eksperimen dengan kelompok kontrol pada siswa SMAN 8 Surakarta dengan peningkatan rata-rata sebesar 1,18 . Sejalan juga dengan hasil penelitian Widyastuti (2008), yang menyimpulkan bahwa terdapat pengaruh yang signifikan pemberian pendidikan kesehatan terhadap tingkat sikap pasien osteoarttritis dengan nilai $p$ sebesar 0,01 .

\section{SIMPULAN DAN SARAN}

Berdasarkan hasil analisis, maka dapat diambil kesimpulan sebagai berikut:

1. Ada pengaruh pelatihan pencegahan DBD terhadap tingkat pengetahuan siswa di SDN Wirogunan I.

2. Ada pengaruh pelatihan pencegahan DBD terhadap tingkat sikap siswa di SDN Wirogunan I.
Berdasarkan hasil penelitian, maka disampaikan beberapa saran sebagai berikut:

1. Bagi SDN Wirogunan I

SDN Wirogunan I dapat bekerjasama dengan bidang P2PL DKK Sukoharjo untuk membentuk jumantik kecil melalui program Usaha Kesehatan Sekolah (UKS) yang efektif dan berkesinambungan, sehingga dapat meningkatakan upaya Pemberantasan Sarang Nyamuk (PSN) di lingkungan sekolah.

2. Bagi DKK Sukoharjo

DKK Sukoharjo khususnya Bidang P2PL dapat mengoptimalkan peran dokter kecil sebagai kader jumantik kecil melalui program pelatihan dan atau pendidikan kesehatan mengenai DBD di sekolahsekolah tingkat dasar yang ada di wilayah Kabupaten Sukoharjo.

3. Bagi peneliti lain

Penelitian ini masih dapat dikembangkan lagi dengan menambahkan variabel perilaku dan menggunakan desain yang berbeda dengan memberikan kontrol pada subjek penelitian.

\section{DAFTAR PUSTAKA}

Azwar, S., 2011, Sikap Manusia Teori dan Pengukurannya, Pustaka Pelajar, Yogyakarta.

Brahim, R., Hasnawati., Anggraeni, N. D. dan Ismandari, F., 2010, Demam Berdarah Dengue di Indonesia Tahun 1968-2009, Buletin Jendela Epidemiologi, Vol. 2, Agustus 2010, hal: 1-14.

Depkes RI., 2007, Pemberantasan Sarang Nyamuk Demam Berdarah Dengue (PSN DBD) oleh Juru Pemantau Jentik (Jumantik), Depkes RI, Jakarta.

DKK Sukoharjo., 2012, Profil Kesehatan Kabupaten Sukoharjo 2011, DKK Sukoharjo, Sukoharjo.

Fatmawati, A., 2010, Pengaruh Pendidikan Kesehatan tentang Penyakit Menular Seksual terhadap Perubahan Pengetahuan dan Sikap Siswa SMAN 8 Surakarta, Skripsi, Fakultas Ilmu Kesehatan UMS, Surakarta. 
Indrayani, A. D., 2010, Perbedaan Pengetahuan dan Sikap Jumantik Kecil Sebelum dan Sesudah Pemberian Pelatihan Pencegahan Demam Berdarah Dengue (DBD) di MIN Ketitang, Skripsi, Fakultas Ilmu Kesehatan UMS, Surakarta.

Kamil, M., 2010, Model Pendidikan dan Pelatihan (Konsep dan Aplikasi), Alfabeta, Bandung.

Kemkes RI., 2011, Profil Kesehatan Indonesia 2010, Kemkes RI, Jakarta.

Kepmenkes No. 1457 Tahun 2003, Tentang Standar Pelayanan Minimal (SPM) Bidang Kesehatan Di Kabupaten/Kota, Kemkes RI, Jakarta.

Notoatmodjo, S., 2007, Promosi Kesehatan dan Ilmu Perilaku, Rineka Cipta, Jakarta.

PKD Wirogunan., 2011, Pencatatan Penyakit DBD di Desa Wirogunan, PKD Wirogunan, Kartasura.

Puskesmas Kartasura., 2012, Data Kasus Demam Berdarah di Puskesmas Kartasura tahun 2010-2011, Puskesmas Kartasura, Kartasura.

Puspitasari, N., 2011, Keefektifan Penyuluhan HIV dan AIDS oleh Waria dalam Meningkatkan Pengetahuan Waria di Surakarta, Skripsi, Fakultas Ilmu Kesehatan UMS, Surakarta.

Rita., 2011, Kampanye Ayo Stop DBD Peran Serta Masyarakat dalam Upaya Memberantas DBD, http://www.depkes.go.id, Diakses tanggal 29 Maret 2012.

Sigarlaki, HJO., 2007, Karateristik, Pengetahuan, dan Sikap Ibu Terhadap Penyakit Demam Berdarah Dengue, Berita Kedokteran Masyarakat, Vol. 23, No. 3, September 2007, hal: 148-153.

Soeparmanto, P., 2006, Peningkatan Penanggulangan Penyakit DBD Berbasis Masyarakat dengan Penyuluhan Kesehatan, Berita Kedokteran Masyarakat, Vol.22, No.2. Juni 2006, hal: 75-81.

Widoyono., 2008, Penyakit Tropis, Epidemiologi, Penularan, Pencegahan dan Pemberantasannya, Erlangga, Jakarta.

Widyastuti, Y., 2008, Pengaruh Pendidikan Kesehatan tentang Penyakit Osteoarthtritis terhadap Tingkat Pengetahuan dan Sikap Pasien Osteoarthtritis Di Wilayah Kerja Puskesmas Gondangrejo Karanganyar, Skripsi, Fakultas Ilmu Kesehatan UMS, Surakarta. 
JURNAL KESEHATAN, ISSN 1979-7621, Vol. 9, No. 2, Desember 2016 